\title{
"To Study The Mental Health Of Senior Secondary Students In Relation To Their Social Intelligence"
}

\author{
Ramesh Singh Bartwal \\ Research Scholar, Faculty of Education, Himgiri Zee University, Dehradun (U.K.) INDIA.
}

\begin{abstract}
The present study aims to compare the Mental Health and Social Intelligence of senior secondary students. A sample of 400 students was drawn adopting simple random sampling technique from Government senior secondary schools of Chamoli district of Uttrakhand and Saharanpur district of Uttar Pradesh. Descriptive survey method was employed to collect the data. The ' $t$ '- test and correlation were used for finding the significance of means and significance of relationship between dependent and independent variables. The study revealed that there were no significance differences in mental health of rural and urban students. The study also explored that there was a positive relationship between mental health and social intelligence.

Keywords: Mental Health, Social Intelligence, rural and urban students.
\end{abstract}

\section{Introduction:}

Mental health is a pretty broad term. Some use it as a simple synonym to describe our brain's health. Mental health describes our social, emotional, and psychological states, all wrapped up into one. Someone who experiences "good" mental health, therefore, has found a balance in his or her social, emotional and psychological areas of life. Generally a person with balance is satisfied and happy with how these areas are performing in their lives, even if it appears to someone else they are not in balance.

We all have mental health just like we all have physical health. And just as we monitor our bodies for potential problems or pain, we should keep tabs on our mental health and try to better recognize when it needs some attention. Mental health is "a state of well-being in which the individual realizes his or her own abilities, can cope with the normal stresses of life, can work productively and fruitfully, and is able to make a contribution to his or her community." There is emerging evidence that positive mental health is associated with improved health outcomes. Bhatia (1982) considers mental health as the ability to balance feelings, desires, ambitions and ideals in one's daily living. It means the ability to face and accept the realities of life.

1.1 Social Intelligence: Intelligence often means that a person knows a lot about many things. In reality, however, there are a few different forms of intelligence that people many times overlook. One of these types of intelligence is Social intelligence. This is essentially the ability to properly and effectively interact with people in society. Another form of intelligence that has a very close connection with social intelligence is emotional intelligence. In order to effectively interact with people one must be able to read emotions and have the capability to channel one's own emotions appropriately in different situations. This is a very important skill that people often neglect. Being intelligent is not just about knowing how to final the area of a circle or knowing how gravity works. Intelligence is that people often refer to a very constricted term. Our IQ may be foundation for how mentally brilliant we are but, our emotional intelligence is just as important if not more important in regards to our lives. In order to properly function in today's society, it is imperative that a person knows how to interact with others. One must be able to effectively communicate with others in many environments in the life, whether the person is at work or at home. For this, emotion and social intelligence play a crucial part in success throughout our lives.

Social intelligence describes the exclusively human capacity to use very large brains to effectively navigate and negotiate complex social relationships and environments. Nicholas Humphrey points to a difference between intelligence and social intelligence. Some autistic children are extremely intelligent because they are very good at observing and memorising information, but they have low social intelligence.

In 1983, Howard Gardner, a Harvard professor, shook the world with his Multiple Intelligences theory in Frames of Mind, later in 1993 with Multiple Intelligences: New Horizon, and lately with Five Minds for the Future. He has re-shaped how we think about our potentials and how we see the world. He has shown us how we are multi-dimensional human beings and that we can tap into whatever we own inside to succeed. According to Albrecht, the plain definition of "social intelligence" is the ability to get along well with others and to get them cooperate with you. It is within the line of good people skills and interpersonal skills, but it has something extra. 
Edward L. Thorndike maintained that there are three intelligences: abstract, mechanical, and social. Daniel Goleman explain a groundbreaking synthesis of the latest finding in biology and brain science, revealing that we are "wired to connect " and the surprisingly deep impact of our relationships on every aspects of our lives. Social intelligence is also called behavioral intelligence. To conclude social intelligence is the human capacity to understand what is happening in the society and responding to that understanding in the personality and socially effective manner.

\section{Reviews of related Studies:}

Veereshwar (1979) studied the mental health and adjustment problems of college going girls. A sample of 406 girls in the age group of 18-20 years was taken from the undergraduate students. There was a significant difference in the area of family adjustment between urban and rural girls. The difference in adjustment of urban and rural girls was not significant in the area of health. Both groups showed quite satisfactory health adjustment.

Anand (1989) studied mental health of high school students. The mental health of class X students in the age group 14-15 years age was investigated. A sample of 262 high school students (169 boys and 93 girls) participated in the study. He found on his study the mental health of students, their academic achievement and the educational and occupational status of parents were positively related.

Danni (2000) pointed out in his study that social intelligence was significantly related to tactic other enhancement. It was found that global impression management score was influenced only by neuroticism dimension of personality. The interaction effect of social intelligence and job cadre was found to be significant for impression management global score. The effect of neuroticism as well as social intelligence was significant for tactics changing with the situation and opinion conformity.

H. Kaur and A. Kalaramna (2004) conducted on his study to assess the existing levels of interrelationship between home environment, social intelligence and socio-economic status across various age levels and two sexes. Home environment also showed positive impact on social intelligence.

Prathima H. P. \& Dr. U. Kulsum (2013) examined the relationship between secondary school teachers' social intelligence and their mental health and also find out the effect of different level of social intelligence of teachers on their Mental Health. The participants were 150 secondary school teachers. The findings of the study showed that there was a significant relationship between secondary school teachers' social intelligence and their mental health. The significant difference exists between male and female secondary school teachers' mental health. The results indicated that higher the social intelligence the teachers had the better mental health they possessed.

\section{Objective of the Study:}

1. To compare the mental health of male and female senior secondary students of rural and urban area.

2. To compare the social intelligence of male and female senior secondary students of rural and urban area.

3. To study the relationship between mental health and social intelligence of male and female senior secondary students of rural and urban area.

\section{Hypotheses of the Study:}

Following hypotheses were framed for testing the present study:

1. There is no significant difference between mental health of male and female senior secondary students of rural and urban area.

2. There is no significant difference between social intelligence of male and female senior secondary students of rural and urban area.

3. There is a significant relationship between mental health and social intelligence of male and female senior secondary students of rural and urban area.

\section{Method and Procedure:}

5.1 Design of the Study: For the purpose of the present investigation, descriptive survey method was employed.

5.2 Sample of the Study: The sample of the study consisted of 400 senior secondary students out of which 200 students were taken from urban and 200 from rural areas. A simple random technique of sampling was used. Further 100 male and 100 female students were selected from each area. These students were drawn from different senior secondary schools / Inter colleges of District Chamoli of Uttrakhand and District Saharanpur of Uttar Pradesh.

5.3 Tools Used for Research Study: In order to collect the data for the present investigation, following tools were tools were employed in the present study:

1. Mental Health Battery (MHB) developed by Dr. A.K. Singh and Dr. A.S. Gupta (2000).

2. Social Intelligence Scale (SIS) developed by Dr. N.K. Chaddha and Ms. Usha Ganesan

(2004). 


\subsection{Statistical Techniques Used:}

The techniques were adopted for analyses in the present investigation were:

1. Mean 2. Standard Deviation 3. t- test 4. Correlation

VI. Analysis of Data and Interpretation of Results:

hypotheses.

The present section deals with the analysis of data and discussion of result in order to test the various

Hypothesis 1: There is no significant difference between mental health of male and female senior secondary students of rural and urban area.

To test Hypothesis 1, Table 1 and 2 were prepared.

Table 1: Mean, S.D and t-value to locate difference in mental health scores of rural male and female

\begin{tabular}{|c|c|c|c|c|c|c|}
\hline $\begin{array}{l}\text { Sr. } \\
\text { No. }\end{array}$ & Group & N & Mean & S.D & t-test & $\begin{array}{c}\text { Level of } \\
\text { significance }\end{array}$ \\
\hline 1. & Male students & 100 & 82.70 & 8.75 & \multirow{2}{*}{1.60} & N.S \\
\hline 2. & Female students & 100 & 80.87 & 7.39 & & \\
\hline
\end{tabular}

*Not Significant at 0.01 and 0.05 levels.

6.1 Results: Table 1 shows the mean difference between mental health of rural male and female students. The tvalue testing the significance of mean difference observed in mental health between male and female students is 1.60, which is not significant at 0.01 and 0.05 levels. The result also supported by Tejpreet Kang and Asha Chawla in 2009.

Table 2: Mean, S.D and t-value to locate difference in mental health scores of urban male and female

\begin{tabular}{|l|l|l|l|l|l|l|}
\hline $\begin{array}{l}\text { Sr. } \\
\text { No. }\end{array}$ & Group & N & Mean & S.D & t-test & $\begin{array}{l}\text { Level } \\
\text { significance }\end{array}$ \\
\hline 1. & Male students & 100 & 82.60 & 7.33 & \multirow{2}{*}{0.343} & Not significant \\
\hline 2. & Female students & 100 & 82.25 & 7.72 & & \\
\hline
\end{tabular}

*Not Significant at 0.01 and 0.05 levels.

6.2 Results: Table 2 shows the mean difference between mental health of urban male and female students. The $\mathrm{t}$-value testing the significance of mean difference observed in mental health between male and female students is 0.343, which is not significant at 0.01 and 0.05 levels. The result also supported by Aghara (1995).

Hypothesis 2: There is no significant difference between social intelligence of male and female senior secondary students of rural and urban area.

To test Hypothesis 2, Table 3 and 4 were prepared.

Table 3: Mean, S.D and t-value to locate difference in social intelligence scores of rural male and female students.

\begin{tabular}{|c|cc|c|c|c|c|c|}
\hline Sr. No. & Group & $\mathbf{N}$ & Mean & S.D & t-test & Level of significance \\
\hline 1. & Male students & 100 & 100.54 & 7.53 & \multirow{2}{*}{1.86} & \multirow{2}{*}{ Not significant } \\
\hline 2. & Female students & 100 & 102.40 & 6.93 & & \\
\hline
\end{tabular}

*Not Significant at 0.01 and 0.05 levels.

6.3 Results: Table 3 shows the mean difference between social intelligence of rural male and female students. The t-value testing the significance of mean difference observed in social intelligence between male and female students is 1.86 , which is not significant at 0.01 and 0.05 levels.

Table 4: Mean, S.D and t-value to locate difference in social intelligence scores of urban male and female students.

\begin{tabular}{|c|c|c|c|c|c|c|}
\hline $\begin{array}{l}\text { Sr. } \\
\text { No. }\end{array}$ & Group & N & Mean & S.D & t-test & Level of significance \\
\cline { 1 - 5 } 1. & Male students & 100 & 100.77 & 9.14 & \multirow{2}{*}{1.50} & \multirow{2}{*}{ Not significant } \\
\hline 2. & Female students & 100 & 102.60 & 8.18 & & \\
\hline
\end{tabular}

*Not Significant at 0.01 and 0.05 levels. 
6.4 Results: Table 4 shows the mean difference between social intelligence of urban male and female students. The t-value testing the significance of mean difference observed in social intelligence between male and female students is 1.50, which is not significant at 0.01 and 0.05 levels. The result also supported by A.Sekhri (2009).

Hypothesis 3: There is a significant relationship between mental health and social intelligence of male and female senior secondary students of rural and urban area.

Table 5: Coefficient of Correlation between Mental Health and Social Intelligence of Rural Male Students:

\begin{tabular}{|l|c|c|c|}
\hline Sl. No. & Variables & r & Level of Significance \\
\hline 1. & $\begin{array}{c}\text { Mental health and Social Intelligence } \\
\text { (Rural male students) }\end{array}$ & -0.150 & $\mathrm{~S}^{*}$ \\
\hline
\end{tabular}

* Significant at 0.01 and 0.05 levels.

6.5 Result: As shown in table 5, the coefficient of correlation between mental health and social intelligence is -0.150 , which is significant at 0.01 and 0.05 level. Therefore, our hypothesis 3 that, "There is a significant relationship between mental health and social intelligence of rural male students" has been accepted.

Table 6: Coefficient of Correlation between Mental Health and Social Intelligence of Rural Female Students:

\begin{tabular}{|l|l|c|c|}
\hline Sl. No. & Variables & r & Level of Significance \\
\hline 1. & $\begin{array}{l}\text { Mental health and Social Intelligence } \\
\text { (Rural female students) }\end{array}$ & 0.857 & S* \\
\hline
\end{tabular}

* Significant at 0.01 and 0.05 levels.

6.6 Result: As shown in table 6, the coefficient of correlation between mental health and social intelligence is 0. 857, which is significant at 0.01 level and 0.05 level. Therefore, our hypothesis 3 that, "There is a significant relationship between mental health and social intelligence of rural female students" has been accepted.

Table 7: Coefficient of Correlation between Mental Health and Social Intelligence of Urban Male Students:

\begin{tabular}{|l|c|c|c|}
\hline No. Sl. & Variables & r & Level of Significance \\
\hline 1. & $\begin{array}{c}\text { Mental health and Social Intelligence } \\
\text { (Urban male students) }\end{array}$ & 0.206 & S* $^{*}$ \\
\hline
\end{tabular}

* Significant at 0.01 and 0.05 levels.

8.9 Result: As shown in table 7, the coefficient of correlation between mental health and social intelligence is 0.206 , which is significant at 0.01 level and 0.05 level. Therefore, our hypothesis 3 that, "There is a significant relationship between mental health and social intelligence of urban male students" has been accepted.

Table 8: Coefficient of Correlation between Mental Health and Social Intelligence of Urban Female Students:

\begin{tabular}{|l|l|c|c|}
\hline Sl. No. & Variables & $\mathbf{r}$ & Level of Significance \\
\hline 1. & $\begin{array}{l}\text { Mental health and Social Intelligence } \\
\text { (Urban female students) }\end{array}$ & 0.061 & $\mathrm{~S}^{*}$ \\
\hline
\end{tabular}

* Significant at 0.01 and 0.05 levels.

8.10 Result: As shown in table 8, the coefficient of correlation between mental health and social intelligence is 0.061 , which is not significant at 0.01 level and 0.05 level. Therefore, our hypothesis 3 that, "There is a significant relationship between mental health and social intelligence of urban female students" has been rejected.

\section{Conclusions:}

The investigator found that, there was no significant difference in rural and urban male and female students which shows that the mental health is present in same amount in both sexes and locales. The investigator also found that, there was no significant gender difference with regard to social intelligence among rural and urban students. Since socially intelligent is the one who is cooperative with others, who can make friends, who has wholesome recreational, interests, who gets mixed with members of opposite sex , who has good manners and who has good control, therefore both the sexes having approximately equal level of average social intelligence should be dealt as equal by the teachers as well as society. A significant negative correlation was found out between mental health and social intelligence of rural male students but a positive significant correlation was found between rural female students. Therefore the high level of social intelligence reduces the adverse effect of poor mental health on students. Moreover the findings showed that correlation 
between mental health and social intelligence of rural female students was significant. A significant correlation was found between mental health and social intelligence of urban male students. The similar findings support by Prathima H. P. \& Dr. U. Kulsum (2013) on their study to examine the relationship between secondary school teachers' social intelligence and their Mental Health and also find out the effect of different level of social intelligence of teachers on their Mental Health. The findings of the study showed that there was a significant relationship between secondary school teachers' social intelligence and their mental health. The significant difference exists between male and female secondary school teachers' mental health Therefore, the students possessing high social intelligence level would have better degree of coping with the mental health. It was found that there was no significant relationship mental health and social intelligence of urban female students. However the studies showed that correlation between mental health and emotional intelligence of male urban students was found to be significant.

\section{References:}

[1]. Anuradha sekhari(2009). Mental health of undergraduate students in relation to social and emotional intelligence. Unpublished M.Ed.Dissertation. D.S.College of Education. Punjab University Chandigarh.

[2]. Anand (1989). Buch, M.B, 1983-88, Fourth Survey Of Research In Education, Vol -1. New Delhi: NCERT

[3]. Bhan, R.N. (1972). "Deterioration in Interest as a function of Insecure Mental Health during and after the period of certain academic specialization". Ph.D. Psychology Kurukshetra University. In Third Survey of Educational Research. (1978-83). New Delhi, N.C.E.R.T.

[4]. Bruno et al. (2001). Social Intelligence and Leadership. Journal of Social Psychology, 42(1), 133-148.

[5]. Chadha, N. K. \& Ganesan, V. (2004). Manual of Social Intelligence Scale. Agra: National Psychological Corporation.

[6]. Deepti Hooda (2009). Social Intelligence as a Predictor of Positive Psychological Health.

[7]. Kurukshetra University, Kurukshetra. Journal of the Indian Academy of Applied Psychology,Vol. 35, No.1, 143-150

[8]. Gupta, A.S. \& Singh, A.K. (2000). Manual of mental health battery. National psychological Corporation, Agra.

[9]. Mangrota, H.P. (1982). Mental health as correlate of intelligence, educational achievement and socio-economic status. In M.B. Buch's (Ed.), Third Survey of Research in Education. New Delhi: NCERT, 313.

[10]. Prathima H. P. \& Dr. Umme Kulsum (2013) Relationship between Social Intelligence and Mental Health of Secondary School Teachers. A published research paper. Research Scholar, Department of Education, Bangalore University, Bangalore. Paripex Indian Journal of Research. Volume: 2 | Issue: 11 | Nov 2013

[11]. Sumanlata Saxena And Rajat Kumar Jain (2013) Social Intelligence of Undergraduate Students In Relation To Their Gender and Subject Stream. IOSR Journal of Research \& Method in education (IOSR-JRME) Volume 1, Issue 1 PP 01-04. Retrieve from www.iosrjournals.org www.iosrjournals.org on 29 Nov13.

[12]. Thorndike, R. L., \& Stein, S. (1937). An evaluation of the attempts to measure social intelligence. Psychological Bulletin, 34, 275284.

[13]. Veereshwar, P. (1979). Mental Health and Adjustment Problems of College going Girls, Urban and Rural Department of psychology. Meerut University (ICSSR financed). In Fourth Survey of Educational Research. (1983-88). New Delhi, N.C.E.R.T. 